\title{
KINERJA PENDIDIK YANG MAKSIMAL MENINGKATKAN PRESTASI BELAJAR PESERTA DIDIK
}

\author{
Mortan Sibarani \\ Sekolah Tinggi Teologi Injili Arastamar (SETIA) Jakarta
}

\begin{abstract}
Abstrak
Kinerja pendidik formal belum maximal di negara Indonesia. Masih menghadapi pekerjaan yang berat dan belum bisa dituntaskan oleh lembaga pendidikan yang menghasilkan guru.. Para guru lulusan Lembaga PendidikanTinggi Kependidikkan (LPTK). sudah banyak melakukan inovasi dalam meningkakan mutu guru, namun tidak dapat dihindari lulusan-lulusan lembaga yang menghasilkan guru, belum secara signifikan meningkatkan kwalitas pendidikan, bahkan kurang mampu bersaing dengan lulusan negara lain.
\end{abstract}

Kata kunci: pendidik, prestasi, peserta didik

\section{PENDAHULUAN}

Kinerja pendidik formal belum maksimal di negara Indonesia. Masih menghadapi pekerjaan yang berat dan belum bisa dituntaskan oleh lembaga pendidikan yang menghasilkan guru.. Para guru lulusan Lembaga PendidikanTinggi Kependidikkan (LPTK). sudah banyak melakukan inovasi dalam meningkakan mutu guru, namun tidak dapat dihindari lulusan-lulusan lembaga yang menghaqsilkan guru, belum secara signifikan meningkatkan kwalitas pendidikan, bahkan kurang mampu bersaing dengan lulusan negara lain.

Setiap individu yang diberi tugas atau kepercayaan untuk bekerja pada suatu organisasi kependidikan, diharapkan mampu menunjukkan kinerja yang memuaskan dan memberikan kontribusi yang maksimal terhadap pencapaian tujuan pendidikan. Sudah jelas tujuan organisasi kependidikan adalah menghasilkan lulusan yang bermutu, agar dapat bersaing memasuki dunia kerja. Dengan demikian, apabila dunia sekolah yang berbasis pendidikan dengan dunia kerja senatiasa memiliki hubungan yang signifikan, maka hal ini akan memberi dampak bagi kemajuan bangsa.

Guru hendaknya diatur dengan kesesuaian antara bidang kompetensi dengan jenis pekerjaannya. Kinerja seseorang dapat ditingkatkan bila ada kesesuaian antara pekerjaan dan keahlianya, begitu pula halnya dengan penempatan guru pada bidang tugasnya. Bila pendidik diberikan tugas tidak sesuai dengan keahlianya, maka akan berakibat menurunnya cara kerja dan hasil pekerjaannya, dan menimbulkan rasa tidak puas pada diri mereka. Untuk itu diperlukan dorongan yang kuat dalam memaximalkan kinerja guru.

\section{Pembahasan \\ A. CIRI KINERJA PENDIDIK}

Menurut Undang-undang Sisdiknas No. 20 Tahun 2003, Tenaga kependidikan yang berkualitas sebagai guru, dosen, konselor, pamong belajar, tutor, instruktur, fasilitator sesuai dengan kekhususannya serta partisipasinya dalam pendidikan. 
Pendidik yang Profesional berarti orang yang memiliki kepandaian khusus untuk menjalankan pekerjaan tersebut. Ada pembayaran karena menjalankan tugasnya. Menyandang profesi atau penampilan dalam melakukan pekerjaannya sesuai dengan bidang keahliannya. Standar unjuk kerja bagi pendidik professional adalah adanya aturan baku dan jelas. Kemudian Ada lembaga yang menghasilkan standar akademik yang memadai dalam pengembangan ilmu pengetahuan, dan ada organisasi profesi yang mewadahi para pelaku dalam memperjuangkan eksistensi.

Kinerja Pendidik dalam meningkatkan prestasi belajar merefleksikan kesuksesan suatu organisasi kependidikan. Maka dipandang penting untuk mengukur karakteristik tenaga kerjanya sebagai pendidik yang professional.. Kinerja pendidik merupakan kombinasi yang melekat dan saling berkaitan antara lain paedagogis, professional, sosial, dan personal. Keteladanan dan keterampilan, keadaan dan kondisi internal serta eksternal menentukan keberhasilan kinerja pendidik. Tingkat keterampilan merupakan bahan mentah yang dibawa seseorang ketempat kerja seperti pengalaman, kemampuan, kecakapan-kecakapan antar pribadi serta kecakapan antar teknik. Pengalaman kinerja pendidik dalam menjalankan tugasnya turut menyumbang kinerja yang maximal sehingga tercapai kompetensi lulusan yang diharapkan.

Moral kerja positif pendidik adalah suasana bekerja yang gembira, bekerja bukan dirasakan sebagai sesuatu yang dipaksakan melainkan sebagai sesuatu yang menyenangkan. Moral kerja positif ialah mampu mencintai tugas sebagai suatu yang memiliki nilai keindahan di dalamnya. Jadi kinerja dapat ditingkatkan dengan cara memebrikan pekerjaan seseorang sesuai bidang kemampuanya sendiri. Kinerja dipengaruhi juga oleh kepuasan kerja yaitu perasaan individu terhadap pekerjaan yang memberikan kepuasan batin kepada seseorang sehingga pekerjaan itu disenangi dan digeluti dengan baik.

Kompetensi guru sangat penting karena menyangkut kemampuan atau kesanggupan guru dalam mengelola pembelajaran. Titik tekannya adalah kemampuan guru dalam pembelajaran bukanlah apa yang harus dipelajari (learning what to be learnt), guru dituntut mampu menciptakan dan menggunakan keadaan positif untuk membawa mereka ke dalam pembelajaran agar anak dapat mengembangkan kompetensinya. ${ }^{1}$ Aspek-aspek teladan mental guru berdampak besar terhadap iklim belajar dan pemikiran pelajar yang diciptakan guru. Guru harus memahami bahwa perasaan dan sikap siswa akan terlibat dan berpengaruh kuat pada proses belajarnya.

Kompetensi Keterampilan proses belajar mengajar adalah penguasaan terhadap kemampuan yang berkaitan dengan proses pembelajaran. Kompetensi dimaksud meliputi kemampuan dalam perencanaan, pelaksanaan, dan evaluasi pembelajaran, kemampuan dalam menganalisis, menyusun program perbaikan, serta menyusun program bimbingan dan konseling. Kemampuan mengajar guru sebenarnya merupakan pencerminan penguasan guru atas kompetensinya. Kemampuan mengajar guru yang sesuai dengan tuntutan standar tugas yang diemban memberikan efek positif bagi hasil yang ingin dicapai seperti perubahan hasil akademik siswa, sikap siswa, keterampilan siswa, dan perubahan pola kerja guru yang makin meningkat. Sebaliknya jika kemampuan mengajar yang dimiliki guru sangat sedikit akan berakibat, bukan saja menurunkan prestasi belajar siswa tetapi juga menurunkan tingkat kinerja guru itu sendiri. Untuk keharusan bagi guru untuk dimiliki dalam menjalankan tugas dan fungsinya, tanpa kemampuan mengajar yang baik sangat tidak mungkin guru mampu melakukan inovasi atau kreasi dari materi yang ada dalam

\footnotetext{
${ }^{1}$ Uzer Usman, Menjadi Guru Profesional, (Bandung:PT Remaja Rosdakarya, 2010), 21
} 
kurikulum yang pada gilirannya memberikan rasa bosan bagi guru maupun siswa untuk menjalankan tugas dan fungsi masing-masing.

\section{B. KINERJA PENDIDIK YANG MAKSIMAL}

1. Perencanaan dam Persiapan Mengajar Guru

Tahap perencanaan guru dalam kegiatan pembelajaran adalah tahap yang akan berhubungan dengan kemampuan guru menguasai bahan ajar. Kemampuan guru dalam hal ini dapat dilihat dari cara atau proses penyusunan program kegiatan pembelajaran yang dilakukan oleh guru. Menurut R. Ibrahim dan Nana Syaodih Sukmadinata menyatakan bahwa,

Umumnya guru-guru hanya dituntut menyusun dua macam program pembelajaran, program pembelajaran untuk jangka waktu yang cukup panjang seperti program semesteran (untuk SMP dan SMA), atau program catur wulan (untuk SD), dan program untuk jangka waktu singkat, yaitu untuk setiap satu pokok bahasan. ${ }^{2}$

Sedangkan untuk program pembelajaran jangka waktu yang singkat sering dikenal dengan istilah program pokok/satuan pelajaran,merupakan penjabaran lebih rinci dari program catur wulan/semesteran ditandai oleh adanya unsur-unsur:

\section{Penggunaan Metode Pembelajaran}

Penggunaan metode pembelajaran, guru diharapkan mampu memilih dan menggunakan metode pembelajaran sesuai dengan materi yang akan disampaikan. $\mathrm{R}$. Ibrahim menjelaskan bahwa: "Setiap metode pembelajaran memiliki kelebihan dan kelemahan dilihat dari berbagai sudut, namun yang penting bagi guru metode apapun yang digunakan harus jelas tujuan yang akan dicapai. ${ }^{3}$ Karena siswa memiliki interest sangat baik, idealnya seorang guru harus menggunakan multimetode, yaitu memvariasikan penggunaan metode pembelajaran didalam kelas seperti metode ceramah dipadukan dengan Tanya jawab dan penugasan atau metode diskusi dan pemberian tugas dan seterusnya. Hal ini dimaksudkan untuk menjembatani kebutuhan siswa dan menghindari terjadinya kejenuhan yang dialami siswa.

\section{Keterampilan Mengelola Kelas}

Pengelolaan kelas yaitu keterampilan guru untuk menciptakan dan memelihara kondisi belajar yang optimal dan mengembalikanya bila terjadi gangguan dalam proses pembelajaran, seperti penghentian perilaku siswa yang memindahkan perhatian kelas, memberikan ganjaran bagi siswa yang tepat waktu dalam menyelesaikan tugas.

Komponen-komponen dalam mengelola kelas adalah sebagai berikut:

a. Keterampilan yang berhubungan dengan penciptaan dan pemeliharaan kondisi yang optimal, seperti menunjukkan sikap tanggap, memberikan perhatian, memusatkan perhatian kelompok, memberikan petunjuk yang jelas, menegur bila siswa melakukan tindakan menyimpang, memberikan penguatan

\footnotetext{
${ }^{2}$ Rusman, Model-Model Pembelajaran,(Jakarta:PT Rajagrafindo Persada,2011),76

${ }^{3}$ Rusman, Model-Model Pembelajaran, 78
} 
b. Keterampilan yang berhubungan dengan pengembalian kondisi belajar yang optimal, yaitu berkaitan dengan respons guru terhadap gangguan siswa yang berkelanjutan dengan maksud agar guru dapat melakukan untuk mengembalikan kondisi belajar yang optimal.

c. Menemukan dan memecahkan tingkah laku yang menimbulkan masalah. Hal yang perlu diperhatikan oleh guru dalam pengelolaan kelas adalah, menghindari canpur tangan yang berlebihan, menghentikan penjelasan tanpa alasan, ketidaktepatan memulai dan mengakhiri kegiatan, penyimpangan, dan sikap yang terlalu bertele-tele.

\section{Kegiatan Evaluasi}

Penilaian hasil belajar adalah kegiatan atau cara yang ditunjukkan untuk mengetahui tercapai atau tidaknya tujuan pembelajarandan juga proses pembelajaran yang telah dilakukan. Pada tahap ini seorang guru dituntut memiliki kemampuan dalam menentukan pendekatan dan cara-cara evaluasi, penyusunanan alat-alat evaluasi, pengolahan dan penggunaan hasil evaluasi. Untuk mengetahui keberhasilam kinerja perlu dilakukan evaluasi atau penilaian kerja dengan berpedoman pada seperti produktivitasnya, efektivitas yang menggunakan waktu, dana yang dipakai serta bahan yang tidak terpakai. Sedangkan evaluasi kerja melalui perilaku dilakukan dengan cara membandingkan dan mengukur perilaku seseorang dengan teman sekerja atau mengamati tindakan seseorang dalam menjalankan perintah atau tugas yang diberikan, cara mengkomunikasikan tugas dan pekerjaan dengan orang lain.

Kemampuan lainya yang perlu dikuasai guru pada kegiatan evaluasi atau penilaian hasil belajar adalah menyusun alat evaluasi. Alat evaluasi yang dapat digunakan adalah tes tertulis, tes lisan, dan tes perbuatan. Seorang guru dapat menentukan alat tes tersebut sesuai dengan materi yang disampaikan.

Kinerja guru sangat penting untuk diperhatikan dan dievaluasi karena guru mengemban tugas profesioanal artinya tugas-tugas hanya dapat dikerjakan dengan kompetensi khusus yang diperoleh melalui program pendidikan. Guru memiliki tanggungjawab yang secara garis besar yang dapat dikelompokkan yaitu: guru sebagai pengajar, guru sebagai pembimbing, dan guru sebagai administrator kelas.

\section{Faktor-Faktor Penunjang Kinerja Guru}

Guru merupakan ujung tombak keberhasilan pendidikan dan dianggap sebagai orang yang berperan penting dalam pencapaian tujuan pendidikan yang merupakan pencerminanan mutu pendidikan. ${ }^{4}$ Keberadaan guru dalam melaksanakan tugas dan kewajibannya tidak lepas dari pengaruh faktor internal dan eksternal yang membawa dampak pada perubahan kinerja guru. Beberapa faktor yang mempengaruhi kinerja guru yang dapat diungkap tersebut antara lain:

\section{a. Kepribadian dan Dedikasi}

Setiap guru memiliki pribadi masing-masing sesuai ciri-ciri pribadi yang mereka miliki. Ciri-ciri inilah yang membedakan seorang guru dari guru lainya. Kepribadian sebenarnya adalah suatu masalah abstrak, yang hanya dapat dilihat dari penampilan, tindakan, ucapan, cara berpakaian dan dalam menghadapi setiap persoalan. Zakiah Darajat menyatakan bahwa;

Kepribadian yang sesungguhnya adalah abstrak, sukar dilihat atau diketahui secara nyata, yang dapat diketahui adalah penampilan atau bekasnya dalam segala

\footnotetext{
${ }^{4}$ Khoiru Ahmadi, Pembelajaran Akselerasi, (Jakarta:PT Prestasi Pustakaraya,2011), 183
} 
segi dan aspek kehidupan misalnya dalam tindakanya, ucapan, caranya bergaul, berpakaian dan dalam menghadapi setiap persoalan atau masalah, baik yang ringan maupun yang berat. $^{5}$

Kepribadian adalah keseluruhan dari individu yang terdiri dari unsur psikis, artinya seluruh sikap dan perbuatan seseorang merupakan suatu gambaran dari kepribadian orang itu, dengan kata lain baik tidaknya citra seseorang ditentukan oleh kepribadianya. Faktor yang terpenting bagi seorang guru adalah kepribadianya. Kepribadian inilah yang akan menentukan apakah ia akan menjadi pendidik dan Pembina yang baik bagi anak didiknya ataukah akan menjadi perusak atau penghancur bagi hari depan anak didik, terutama bagi anak didik yang masih kecil dan mereka yang sedang mengalami kegoncangan jiwa. Kepribadian adalah suatu cerminan dari citra seseorang guru akan mempengaruhi interaksi antara guru dan anak didik. Oleh karena itu kepribadian merupakan faktor yang menentukan tinggi rendahnya martabat guru.

Kepribadian guru akan tercermin dalam sikap dan perbuatanya dalam membina dan membimbing anak didik. Semakin baik kepribadian guru, akan semakin baik dedikasinya dalam menjalankan tugas dan tanggungjawabnya sebagai guru, ini berarti tercermin suatu dedikasi yang tinggi dari guru dalam melaksanakan tugas dan fungsinya sebagai pendidik. Salah satu dasar pembentukan kepribadian adalah sukses yang merupakan hasil dari kepribadian, dari citra umum, dari sikap, dari keterampilan karena semua ini melumasi proses interaksi-interaksi antara guru dan peserta didik. ${ }^{6}$

\section{b. Pengembangan Profesi}

Profesi guru semakin hari menjadi perhatian seiring dengan perubahan Ilmu dan Teknologi yang menuntut kesiapan agar tidak ketinggalan. Profesi adalah suatu jabatan atau pekerjaan biasa seperti halnya dengan pekerjaan-pekerjaan lain. Tetapi pekerjaan itu harus diterapkan kepada masyarakat untuk kepentingan masyarakat umum, bukan untuk kepentingan individual, kelompok, atau golongan tertentu. Dalam melaksanakan pekerjaan itu harus memenuhi norma-norma itu. Orang yang melakukan pekerjaan profesi itu harus ahli, orang yang sudah memiliki daya pikir, ilmu dan keterampilan yang tinggi. Disamping itu juga dituntut dapat mempertanggung jawabkan segala tindakan dan hasil karyanya yang menyangkut profesi itu. ${ }^{7}$

Lebih lanjut tentang prodesi sebagaimana dikutip oleh Pidarta mengemukakan ciri-ciri profesi sebagai berikut:

(1) Pilihan jabatan itu didasari oleh motivasi yang kuat dan merupakan panggilan hidup orang yang bersangkutan,

(2) Telah memiliki ilmu, penetahuan dan keterampilan khusus, yang bersifat dinamis dan berkembang terus

(3) Ilmu Pengetahuan, dan keterampilan khusus tersebut di atas diperoleh melalui studi dalam jangka waktu lama di perguruan tinggi

(4) Mempunyai otonomi dalam bertindak ketika melayani klien

(5) Mengabdi kepada masyarakat. ${ }^{8}$

\footnotetext{
${ }^{5}$ Fachruddin Saudagar, Pengembangan Profesionalitas Guru, (Jakarta:GP Press,2009), 39

${ }^{6}$ Saudagar, Pengembangan Profesionalitas, 41

${ }^{7}$ Dadi Permadi, dan Daeng Arifin, 11

${ }^{8}$ Saudagar, Pengembangan Profesionalitas, 6
} 
Bila diperhatikan ciri-ciri profesi tersebut di atas nampaknya bahwa profesi guru tidak mungkin dikenakan pada sembarang orang yang dipandang oleh masyarakat umum sebagai pendidik. Pekerjaan profesi harus berorientasi pada layanan sosial. Seorang profesional ialah orang yang melayani kebutuhan anggota masyarakat baik secara perorangan maupun kelompok. Sebagai orang yang memberikan pelayanan sudah tentu membutuhkan sikap rendah hati dan budi pekerti. Sikap dan budi pekerti ini menjadi sarana bagi terjalinya hubungan yang baik yang ikut menentukan keberhasilan profesi.

Pengembangan profesi guru merupakan hal penting untuk diperhatikan guna mengantisipasi perubahan dan beratnya tuntutan terhadap profesi guru. Pengembangan profesionalisme guru menekankan kepada penguasaan ilmu pengetahuan atau kemampuan menajemen beserta strategi penerapanya.

\section{c. Kemampuan Guru}

Untuk melaksanakan tugas-tugas dengan baik, guru memerlukan kemampuan. Guru harus memiliki kemampuan merencanakan pengajaran, menuliskan tujuan pengajaran, menyajikan bahan pelajaran, memberikan pertanyaan kepada siswa, mengajarkan konsep, berkomunikasi dengan siswa, mengamati kelas, dan mengevaluasi hasil belajar.

\section{d. Memiliki Komunikasi dengan Sekolah}

Komunikasi merupakan aktivitas dasar manusia, manusia dapat saling berhubungan satu sama lain dalam kehidupan sehari-hari dirumah tangga, di tempat kerja, di pasar, dalam masyarakat atau dimana saja manusia berada. Tidak ada manusia yang tidak akan terlibat komunikasi.

Pentingnya komunikasi bagi organisasi tidak dapat dipungkiri, adanya komunikasi yang baik suatu organisasi dapat berjalan dengan lancar dan berhasil dan begitu pula sebaliknya. Misalnya Kepala Sekolah tidak menginformasikan kepada guru-guru mengenai kapan sekolah dimulai. Sesudah libur maka besar kemungkinan guru tidak akan datang mengajar. Contoh di atas menandakan betapa pentingnya komunikasi. ${ }^{9}$

Guru dalam proses pelaksanaan tugasnya perlu memperhatikan komunikasi yang baik antara guru dengan guru, guru dengan siswa, dan guru dengan karyawan di sekolah. Komunikasi yang baik membawa konsekwensi terjalinnya interaksi seluruh komponen yang ada dalam sistem sekolah. Kegiatan pembelajaran yang dilakukan guru akan berhasil jika ada hubungan dan komunikasi yang baik dengan siswa sebagai komponen yang diajar. Kinerja guru akan meningkat seiring adanya kondisi hubungan dan komunikasi yang sehat di antara komponen sekolah sebab dengan pola hubungan dan komunikasi yang lancar dan baik mendorong pribadi seseorang untuk melakukan tugas dengan baik.

Hubungan sosial antar manusia selalu terjadi di lingkungan kerja. Hubungan yang terjadi antara atasan dengan bawahan, bawahan dengan bawahan. Di sekolah hubungan dapat terjadi antara kepala sekolah dengan guru, antara guru dengan guru serta guru dengan siswa. Hubungan guru dengan siswa lebih sering dilakukan dibandingkan dengan hubungan guru dengan guru atau hubungan guru dengan kepala sekolah. Setiap hari guru harus berhadapan dengan siswa yang jumlahnya cukup banyak yang terkadang sangat merepotkan tetapi bagi guru interaksi dengan siswa

\footnotetext{
${ }^{9}$ Beni S. Ambarjaya, Psikologi Pendidikan dan Pengajaran, (Yogyakarta:CAPS, 2012), 111
} 
merupakan hal sangat menarik dan mengasyikkan apalagi dapat membantu siswa dalam menemukan cara mengatasi kesulitan belajar siswa. ${ }^{10}$

Komunikasi yang dikembangkan guru terutama dalam proses pembelajaran dan pada situasi interaksi lain di sekolah memberikan peluang terciptanya situasi yang kondusif untuk dapat memperlancar pelaksanaan tugas, segala persoalan yang dihadapi guru baik dalam pelaksanaan tugas utama maupun tugas tambahan dapat diselesaikan melalui penyelesaian secara bersama dengan rekan guru yang lain, tanpa hubungan dan komunikasi yang baik di dalam lingkungan sekolah apapun bentuk pekerjaan yang kita lakukan tetap akan mengalami hambatan dan kurang lancar.

Guru dapat mengembangkan kreativitasnya sebab ada jalan untuk terjadinya interaksi dan ada respon balik dari komponen lain di sekolah atas kreativitas dan inovasi tersebut, hal ini menjadi salah satu cara bagi guru untuk terus meningkatkan daya inovasi dan kreativitasnya yang bukan saja inovasi dalam tugas utamanya tetapi bisa saja muncul inovasi dalam tugas yang lain yang diamanatkan sekolah. Ini berarti bahwa pembinaan hubungan dan komunikasi yang baik di antara komponen dalam sekolah menjadi suatu keharusan dalam menunjang peningkatan kinerja. Untuk itu semakin baik pembinaan hubungan dan komunikasi dibina maka respon yang muncul semakin baik pula yang pada gilirannya mendorong peningkatan kinerja.

\section{e. Hubungan Dengan Masyarakat}

Sekolah merupakan lembaga sosial yang tidak dapat dipisahkan dari masyarakat lingkungannya, sebaliknya masyarakat pun tidak dapat dipisahkan dari sekolah sebab keduanya memiliki kepentingan, sekolah merupakan lembaga formal yang diserahi mandat untuk mendidik, melatih, dan membimbing generasi muda bagi peranannya di masa depan, sementara masyarakat merupakan pengguna jasa pendidikan itu.

Hubungan sekolah dengan masyarakat merupakan bentuk hubungan komunikasi ekstern yang dilaksanakan atas dasar kesamaan tanggung jawab dan tujuan. Masyarakat merupakan kelompok individu-individu yang berusaha menyelenggarakan pendidikan atau membantu usaha-usaha pendidikan. Dalam masyarakat terdapat lembaga-lembaga penyelenggaran pendidikan, lembaga keagamaan, kepramukaan, politik, sosial, olah raga, kesenian yang bergerak dalam usaha pendidikan. Dalam masyarakat juga terdapat individu-individu atau pribadipribadi yang bersimpati terhadap pendidikan di sekolah. Hubungan sekolah dengan masyarakat adalah suatu proses komunikasi antara sekolah dengan masyarakat untuk meningkatkan pengertian masyarakat tentang kebutuhan serta kegiatan pendidikan serta mendorong minat dan kerjasama untuk masyarakat dalam peningkatan dan pengembangan sekolah. Hubungan sekolah dengan masyarakat ini sebagai usaha kooperatif untuk menjaga dan mengembangkan saluran informasi dua arah yang efisien serta saling pengertian antara sekolah, dengan masyarakat.

\section{KESIMPULAN}

\footnotetext{
${ }^{10}$ Ambarjaya, Psikologi Pendidikan dan Pengajaran, 116
} 
KINERJA PENDIDIK YANG MAXIMAL ... (Mortan Sibarani)

Berbagai usaha telah dilakukan pemerintah dalam memperbaiki kinerja guru, di antaranya mengikuti Pendidikan Profesi Guru (PPG), mengadakan Musyawarah Guru Mata Pelajaran (MGMP), memberikan tunjangan profesi, namun belum berdampak signifikan terhadap peningkatan mutu pendidikan nasional. Untuk itu perlu strategi inovasi baru dalam meningkatkan kinerja guru. Bagaimanapun guru menjadi sentral penting bagi pencerdaskan bangsa.

\section{Referensi}

Usman Uzer, Menjadi Guru Profesional, Bandung:PT Remaja Rosdakarya, 2010. Rusman, Model-Model Pembelajaran, Jakarta: PT Rajagrafindo Persada, 2011. Ahmadi Khoiru, Pembelajaran Akselerasi, Jakarta:PT Prestasi Pustakaraya, 2011. Saudagar Fachruddin, Pengembangan Profesionalitas Guru, Jakarta: GP Press, 2009. Ambarjaya Beni S., Psikologi Pendidikan dan Pengajaran, Yogyakarta:CAPS, 2012. Undang-undang Sisdiknas No. 20 tahun 2003. 